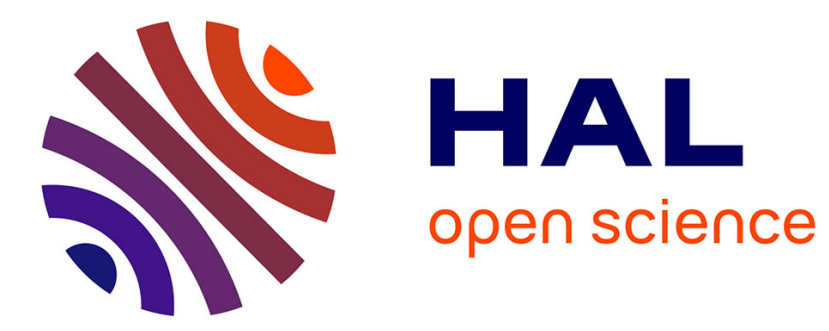

\title{
The immune response of ruminant livestock to bluetongue virus:From type I interferon to antibody
}

N. James Maclachlana, Christine Henderson, Isabelle Schwartz-Cornil, Stéphan Zientara

\section{- To cite this version:}

N. James Maclachlana, Christine Henderson, Isabelle Schwartz-Cornil, Stéphan Zientara. The immune response of ruminant livestock to bluetongue virus:From type I interferon to antibody. Virus Research, 2014, 182, pp.71-77. 10.1016/j.virusres.2013.09.040 . hal-01190011

\section{HAL Id: hal-01190011 \\ https://hal.science/hal-01190011}

Submitted on 1 Sep 2015

HAL is a multi-disciplinary open access archive for the deposit and dissemination of scientific research documents, whether they are published or not. The documents may come from teaching and research institutions in France or abroad, or from public or private research centers.
L'archive ouverte pluridisciplinaire HAL, est destinée au dépôt et à la diffusion de documents scientifiques de niveau recherche, publiés ou non, émanant des établissements d'enseignement et de recherche français ou étrangers, des laboratoires publics ou privés. 


\title{
The immune response of ruminant livestock to bluetongue virus: From type I interferon to antibody
}

\author{
N. James Maclachlan ${ }^{\mathrm{a}, *}$, Christine Henderson ${ }^{\mathrm{b}}$, Isabelle Schwartz-Cornil ${ }^{\mathrm{c}}$, \\ Stephan Zientara ${ }^{\mathrm{C}}$ \\ a Department of Pathology Microbiology and Immunology, School of Veterinary Medicine, University of California, Davis, CA 95616, USA \\ b Merial Inc., Athens, GA 30601, USA \\ c ANSES Alfort, UMR 1161 ANSES/INRA/ENVA-UPEC, 23 Av du Général de Gaulle, BP 63, 94703 Maisons-Alfort Cédex, France
}

\section{A R T I C L E I N F O}

\section{Article history:}

Available online 10 October 2013

\section{Keywords:}

Bluetongue virus

Immune response

Innate

Adaptive

\begin{abstract}
A B S T R A C T
Infection of ruminants with most (but not all) serotypes of bluetongue virus (BTV) leads to a highly blood cell-associated viremia that may be prolonged but not persistent. Furthermore, recovered animals are resistant to reinfection with the homologous virus serotype, which is the basis for vaccination strategies to prevent BTV infection and the clinical disease (bluetongue) that it causes in domestic livestock. BTV infection is initiated at the site of virus inoculation and the associated draining lymph node, from where the virus is then spread in lymph cells to the systemic circulation and secondary sites of replication. Replication of BTV in target cells, notably mononuclear phagocytic cells (dendritic cells and macrophages) and endothelium, leads to the generation of the innate and adaptive immune responses that mediate both initial virus clearance and subsequent resistance to infection with the homologous virus serotype. The goal of this review is to summarize current understanding of these innate and adaptive immune responses of animals to BTV infection.
\end{abstract}

(C) 2013 Elsevier B.V. All rights reserved.

\section{Introduction}

Bluetongue (BT) is an arboviral disease of domestic and wild ruminants characterized by vascular injury that results in tissue necrosis, hemorrhage, and edema (Hutcheon, 1902; Maclachlan et al., 2009; Spreull, 1905; Verwoerd and Erasmus, 2004). The causative agent of BT is bluetongue virus (BTV), the prototype member of the genus Orbivirus, family Reoviridae (Borden et al., 1971; Matsuo and Roy, 2013; Murphy et al., 1971; Schwartz-Cornil et al., 2008). The BTV virion consists of a diffuse outer protein coat and an inner icosahedral core that encloses the transcriptase complex (Stewart et al., 2012; Verwoerd et al., 1972). The genome includes 10 distinct genome segments of double-stranded RNA (dsRNA). Each gene segment encodes at least 1 protein, specifically 7 structural (VP1-7) and 5 nonstructural (NS1-3/3A, 4) proteins (Grubman et al., 1983; Mertens et al., 1984; Ratinier et al., 2011). Some 26 BTV serotypes are now recognized globally (Hofmann et al., 2008; Maan et al., 2012).

BTV infection occurs throughout temperate and tropical regions of the world coincident with the distribution of specific species of vector Culicoides biting midges, however the global distribution

\footnotetext{
* Corresponding author. Tel.: +1 5307548125.

E-mail address: njmaclachlan@ucdavis.edu (N.J. Maclachlan).
}

of BTV has recently altered markedly, particularly in the northern hemisphere (Gibbs and Greiner, 1994; Maclachlan, 2011; Maclachlan and Mayo, 2013; Saegerman et al., 2008; Tabachnick, 2010). Thus, BT is viewed currently as a globally emerging disease (Gibbs et al., 2008; Guis et al., 2012; Jiminez-Clavero, 2012; Maclachlan and Guthrie, 2010; Purse et al., 2008; Weaver and Reisen, 2010). Outbreaks of BT can be economically devastating to livestock production and the presence of BTV in a country can adversely impact the trade and movement of livestock (Maclachlan and Osburn, 2006; Velthuis et al., 2010). Control of BTV infection and BT disease can be difficult, and prevention of the disease is typically reliant on vaccination of susceptible livestock (reviewed: Maclachlan and Mayo, 2013). Sound vaccination strategies should logically be based on a thorough understanding of the ruminant immune response to BTV, which is the focus of this review.

\section{Innate immunity}

The innate immune response constitutes the first line of defense of animals against viral infections. Innate immune mechanisms are also critical to transition to an effective adaptive immune response (humoral and cellular). Natural BTV infection of ruminants typically occurs following the bite of any one of the multiple species of hematophagous Culicoides midges that serve as biological vectors of the virus (Barratt-Boyes and Maclachlan, 1995; Gibbs and 
Greiner, 1994; Mellor et al., 2000; Tabachnick, 2010; Verwoerd and Erasmus, 2004). After cutaneous instillation of BTV following the bite of an infected midge, the virus is quickly translocated in dendritic cells to the regional lymph node where initial replication occurs (Barratt-Boyes and Maclachlan, 1994; Ellis et al., 1991; Hemati et al., 2009; Pini, 1976). Conventional dendritic cells are recruited in large numbers to the skin following virus infection, facilitating further replication of the virus at the site of initial infection in the skin (Hemati et al., 2009). Interruption of lymphatic flow to the regional lymph node adjacent to the site of virus inoculation markedly delays the onset of viremia (Barratt-Boyes and Maclachlan, 1994).

Initial replication of BTV in the regional lymph node likely occurs in dendritic cells, macrophages, endothelium and possibly lymphocytes, as these are major cellular targets of BTV (Maclachlan et al., 2009; Darpel et al., 2012). In vitro BTV infection of ovine conventional dendritic cells from skin lymph leads to the production of proinflammatory and immune cytokines (interleukins [IL-1 $\beta$, IL-6, IL-12]) as well as to expression of co-stimulatory molecules that promote the proliferation of BTV-specific CD4+ and CD8+ T cells (Hemati et al., 2009). Similarly, in vitro BTV infection of bovine monocyte - derived macrophages leads to their activation with production of tissue necrosis factor (TNF- $\alpha$ ), interleukins (e.g. IL$1 \beta$, IL-8) and inducible nitric oxide synthetase (Drew et al., 2010a). Replication of BTV in the regional lymph node stimulates a marked cellular response characterized by increased numbers of B cells within the node itself and the appearance of virus-specific antibodies and activated CD8+ T cells in the draining efferent lymph (Barratt-Boyes et al., 1995).

Following initial replication of BTV at the site of inoculation and within the adjacent draining lymph node, the virus is then disseminated to a variety of tissues throughout the body where secondary replication occurs in mononuclear phagocytic cells (macrophages and dendritic cells), endothelial cells, lymphocytes including $\gamma \delta$ T cells, and perhaps other cell types (Barratt-Boyes et al., 1992; Barratt-Boyes and Maclachlan, 1994, 1995; Darpel et al., 2012; DeMaula et al., 2001, 2002; Ellis et al., 1991; Hemati et al., 2009; Lee et al., 2011; Maclachlan et al., 1990, 2009; Mahrt and Osburn, 1986; Umeshappa et al., 2012; Whetter et al., 1989). Viral RNA (especially dsRNA) is detected by pattern recognition receptors (PRR) in the cytoplasmic and endosomal compartments of host cells, notably toll-like receptors (TLRs) or members of the retinoic acid inducible gene (RIG-1)-like family of cytoplasmic receptors (Levy et al., 2011). Different PRR utilize distinct signaling pathways to trigger the production of Type I and Type III IFNs and other proinflammatory cytokines.

It has long been recognized that BTV infection is a strong inducer of Type I IFN, both in vivo and in vitro (Foster et al., 1991; Fulton and Pearson, 1982; Huismans, 1969; MacLachlan et al., 1984; Maclachlan and Thompson, 1985; Russell et al., 1996). Whereas adult mice are resistant to productive BTV infection, Type I $(\alpha / \beta)$ IFN receptor knockout mice (IFNAR $[-/-]$ ) are highly susceptible to lethal infection with the virus (Calvo-Pinilla et al., 2009a, 2010; Franceschi et al., 2011). It recently has been shown that BTV induces Type I IFN production in plasmacytoid dendritic cells via a MYD88dependent TLR7/8-independent sensing and signaling pathway, whereas cytoplasmic helicases (RIG-1, MDA5) mediate sensing and signaling in BTV-infected epithelial cells (Chauveau et al., 2012; Ruscanu et al., 2012). The BTV NS3 protein specifically interferes with IFN production in epithelial cells by inhibiting the RIG1-like receptor mediated signaling pathway (Chauveau et al., 2013). Plasmatocytoid dendritic cells and Type 1 IFN may exert a central role in triggering B cell responses and promoting BTV-specific antibody synthesis (humoral immunity), as has recently been shown for rotavirus, which is another dsRNA virus of the family Reoviridae (Deal et al., 2013).
Infection of dendritic cells, macrophages, endothelial cells and others during BTV infection of ruminants leads to the production of a variety of proinflammatory and vasoactive mediators including Type I IFNs, TNF- $\alpha$, and various interleukins and prostanoids, but the response can vary depending on the cell types that are infected as well as their tissue location (Channappanavar et al. 2012; DeMaula et al., 2001, 2002; Drew et al., 2010a; Hemati et al., 2009; Ruscanu et al., 2012, 2013; Umeshappa et al., 2012). Furthermore, although these virus-induced cytokine and chemokine mediators may serve to limit/control the infection during its initial stages and to promote the development of a strong acquired immune response, they may also contribute to the pathogenesis of the capillary leakage syndrome and coagulopathy that characterizes clinical BT in ruminants-the so-called "cytokine storm" of hemorrhagic fevers (Fig. 1) (Drew et al., 2010b; Maclachlan et al., 2008, 2009; Umeshappa et al., 2012). Thus, the virulence to sheep of different strains/serotypes of BTV is correlated with the severity of the vascular lesions they induce and to serum concentrations of acute phase proteins, and not to viral loads (Sanchez-Cordon et al., 2013). Similarly, DeMaula et al. (2002) showed that vascular injury and enhanced coagulation, as assessed by the ratio of plasma thromboxane to prostacyclin, were significantly greater in sheep than cattle inoculated with the same strain of BTV, consistent with the sensitivity of sheep and relative resistance of cattle to expression of clinical BT.

\section{Cellular immunity}

Cell-mediated immunity (CMI) typically limits viral spread during the initial stages of acute viral infections by the destruction of virus-infected cells (virus factories). Although BTV infection of ruminants clearly results in changes in lymphocyte populations and dynamics both locally (adjacent to the site of infection) and systemically (Barratt-Boyes et al., 1995; Ellis et al., 1990, 1991; Hemati et al., 2009; Umeshappa et al., 2012), the CMI response of ruminants to BTV infection remains poorly characterized. CD8+ cytototoxic T lymphocytes (CTLs) have been identified following BTV infection of both mice and sheep, although their activity is apparently transient and their precise role in mediating virus clearance is poorly defined (Andrew et al., 1995; Calvo-Pinilla et al., 2012; Jeggo and Wardley, 1982a,b; Jeggo et al., 1984, 1986). Adoptive transfer of CTLs harvested from the thoracic duct of a sheep previously infected with BTV partially protected recipient sheep against challenge infection with either homologous or heterologous serotypes of BTV (Jeggo et al., 1984, 1986).

The BTV NS1 and VP2 proteins have been proposed to be major targets of the ovine CMI response to BTV, although the viral protein-specific CTL response of individual sheep can vary markedly (Andrew et al., 1995; Janardhana et al., 1999; Takamatsu and Jeggo, 1989). Ovine CTLs specific for the non-structural NS1 protein are cross reactive amongst different BTV serotypes. Similarly, Calvo-Pinilla et al. (2012) described generation of NS1-specific CD8+ T cells and heterotypic immunity in IFNAR mice that were immunized with recombinant BTV proteins, and Jones et al. (1996, 1997) earlier showed that the BTV nonstructural proteins, especially NS2, can induce cross-reactive CTLs in mice. Together these findings offer some promise that a polyvalent vaccine strategy to prevent BTV infection is potentially feasible, as the NS1 and NS2 proteins are relatively conserved among field strains of BTV regardless of serotype. However, neither homologous nor heterologous protection was obtained with a recombinant adenovirus expressing only the NS1 protein of BTV-2 despite strong induction of proteinspecific CD8+ T cells in the vaccinated sheep (unpublished data). Similarly, although BTV core-like particles that include only VP3 and VP7 have been reported to induce partial protection against 


\section{Role of Mononuclear Phagocytes in BTV Infection}

\section{Viral dissemination}

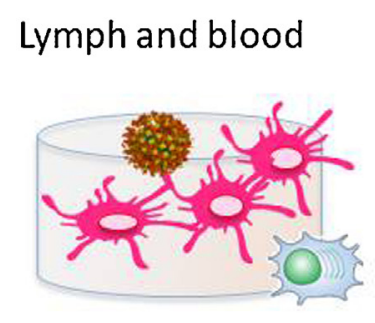

2. Innate response

Virus control/
inflammation/
bleeding/coagulation

\section{Acquired immunity}

\author{
Viral clearance and \\ protection against \\ homologous reinfection
}

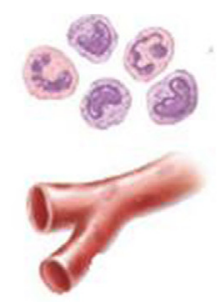

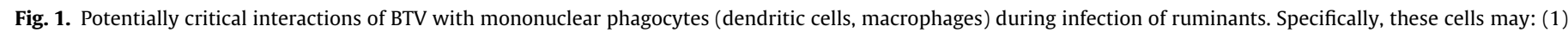

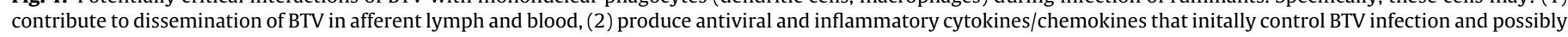

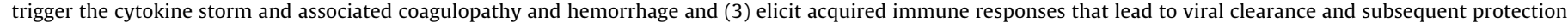
against re-infection with the homologous BTV serotype.

both homologous and heterologous challenge in sheep, complete protection requires immunization with the VP2 of the respective BTV serotype (Roy et al., 1994; Stewart et al., 2012). Thus, despite the potential promise of a polyvalent BTV vaccination strategy based on CMI responses to different BTV proteins, little progress has been made in confirming the viability of such an approach and the precise role of CMI in either mediating virus clearance during primary infection or conferring resistance to reinfection with homologous or heterologous BTV serotypes awaits thorough clarification.

\section{Antibody (humoral) immunity}

BTV infection of ruminants results in the prompt production of antibodies to both structural and nonstructural viral proteins (Huismans and Erasmus, 1981; Maclachlan et al., 1987; Richards et al., 1988). Immune competence of fetal ruminants to BTV infection arises prior to mid-gestation (Osburn et al., 1982; MacLachlan et al., 1984). Antibodies to core protein VP7 are broadly serogroup reactive as this protein is conserved amongst most BTV serotypes and strains, thus detection of antibodies to VP7 is the basis of the competitive ELISA (cELISA) assays that are now widely used for serological diagnosis of BTV infection of livestock (Afshar, 1994; Anderson, 1984; Maclachlan and Mayo, 2013). BTV-specific neutralizing antibodies can confer long-lasting resistance to reinfection with the homologous BTV serotype, which is the basis of vaccination strategies to prevent BT disease (Huismans et al., 1987; Noad and Roy, 2009; Savini et al., 2008; Spreull, 1905; Stewart et al., 2012; Verwoerd and Erasmus, 2004). Interestingly, although neutralizing antibodies confer serotype-specific resistance to reinfection, viremia can continue for extended intervals in the course of primary infection despite the presence of such antibodies (Barratt-Boyes and Maclachlan, 1994, 1995; Bonneau et al., 2002; Foster et al., 1991; Di Gialleonardo et al., 2011; Luedke et al., 1969; Martinelle et al., 2011; Richards et al., 1988). This ability of BTV to avoid neutralization during primary infection is attributed to its intimate association with the cell membranes of circulating blood cells, erythrocytes in particular, which also leads to an extended duration (several months) of reverse-transcriptase-polymerase chain reaction (RT-PCR) positive status of ruminants following BTV infection (Barratt-Boyes and Maclachlan, 1994; Brewer and Maclachlan,
1992, 1994; Di Gialleonardo et al., 2011; Luedke et al., 1969; Maclachlan et al., 1990, 1994, 2009; Martinelle et al., 2011).

The neutralizing epitopes of BTV are localized to specific interactive regions of the VP2 outer capsid protein. Sheep inoculated with VP2 that is either isolated from viral particles or generated by in vitro expression produce virus neutralizing antibodies and are resistant to challenge infection with the homologous BTV serotype (Huismans and Erasmus, 1981; Huismans et al., 1987; Roy et al., 1990, 1992, 1994; Stewart et al., 2012). At least some neutralization epitopes are highly conformationally dependent, reflecting not only folding of the VP2 protein on itself but also its conformational interaction with the other outer capsid protein, VP5 (Appleton and Letchworth, 1983; Cowley and Gorman, 1987; DeMaula et al., 1993, 2000; Gould et al., 1988; Gould and Eaton, 1990; Heidner et al., 1990; Mertens et al., 1989). DeMaula et al. (2000) showed that whereas most variants that were resistant to neutralization with individual neutralizing monoclonal antibodies (MAbs) had amino acid substitutions in key regions of VP2, the VP2 of one MAb-neutralization resistant variant virus was unchanged but this virus had a substitution in VP5, confirming unambiguously the importance of the conformational interaction between VP2 and VP5 in BTV neutralization. Individual neutralizing epitopes are sometimes conserved between serotypes in either a neutralizing or non-neutralizing conformation (Maclachlan et al., 1992; Pierce et al., 1995; Ristow et al., 1988; Rossitto and Maclachlan, 1992; White and Eaton, 1990). The presence of common neutralization epitopes between BTV serotypes is further confirmed by serological cross reactivity of certain serotypes of the virus, and by the fact that animals inoculated or immunized with one or more BTV serotypes can develop neutralizing antibodies against serotypes to which they were never exposed (Dungu et al., 2004; Rossitto and Maclachlan, 1992; Thomas, 1985).

Studies with BTV proteins expressed from recombinant pox, herpes and baculoviruses confirm that induction of neutralizing antibodies and protection of sheep against challenge infection with the homologous BTV serotype is best achieved by co-expression of both the VP2 and VP5 outer capsid proteins, including their co-expression as virus-like particles or in combination with BTV core proteins (Lobato et al., 1997; Ma et al., 2012; Roy et al., 1990, 1992, 1994). Thus, we have utilized the canarypox (CP) virus expression vector to evaluate induction of BTV-neutralizing antibodies in sheep using a CP construct co-expressing both VP2 
Table 1

Effect of immunization of sheep with different doses of recombinant canarypox virus co-expressing the VP2 and VP5 genes of bluetongue virus (BTV) prior to challenge infection with BTV serotype 17.

\begin{tabular}{lllllll}
\hline TREATMENT & SN $^{+}$ & & cELISA $^{++}$ & qRT PCR $^{+++}$ & $\begin{array}{l}\text { Temp. } \\
(>103.5\end{array}$ \\
& & & & & & \\
& Pre $)$ & Post & Pre & Post & & \\
Control & $0 / 4$ & $3 / 3^{*}$ & $0 / 4$ & $3 / 3$ & $4 / 4$ & $4 / 4$ \\
Vaccine-low & $0 / 4$ & $4 / 4$ & $0 / 4$ & $4 / 4$ & $4 / 4$ & $1 / 4$ \\
Vaccine-med & $3 / 4$ & $4 / 4$ & $0 / 4$ & $1 / 4$ & $1 / 4$ & $0 / 4$ \\
Vaccine-high & $4 / 4$ & $4 / 4$ & $0 / 4$ & $0 / 4$ & $0 / 4$ & $0 / 4$ \\
\hline
\end{tabular}

$+\mathrm{SN}=$ serum neutralization test to BTV-17; titer $<10$ considered negative.

${ }^{++}$cELISA = competitive ELISA to BTV core protein VP7 (VMRD).

${ }^{+++}$qRT-PCR $=$quantitative PCR based on detection of BTV S10 gene after challenge infection, as previously described (Boone et al., 2007).

Serological status immediately before and 14 days after (Post) BTV challenge infection.

** 1 sheep died in the course of the study.

and VP5 of a strain of BTV-17 (CP-BTV) (Boone et al., 2007). This recombinant CP-BTV construct confers complete resistance of vaccinated sheep to challenge infection with the homologous virus serotype. In an effort to better establish the protective immunity induced by the recombinant CP-BTV construct we undertook a dose titration/challenge infection study using 16 seronegative sheep housed in insect-secure isolation facilities and methods essentially as previously described (Boone et al., 2007). The sheep were assigned individually to one of four treatment groups: four control sheep were immunized with a $\mathrm{CP}$-vectored vaccine against West Nile virus (Recombitek ${ }^{\circledR}$, Merial, GA); four high dose vaccinated sheep were inoculated subcutaneously and intramuscularly (SC/IM) with $2 \times 10^{8}$ particles of the recombinant CP-BTV construct; four medium dose vaccinated sheep were inoculated SC/IM with $2 \times 10^{7}$ particles of CP-BTV; and four low dose vaccinated sheep were inoculated SC/IM with $2 \times 10^{6}$ particles of CP-BTV. All sheep were immunized twice with their respective inocula at a 3 week interval and then challenged at 3 weeks after booster immunization by SC inoculation of approximately $10^{4.9}$ tissue culture infectious doses of a field strain of BTV-17, as previously described (Boone et al., 2007). All sheep were seronegative by group - specific cELISA prior to challenge (Table 1), confirming that sheep vaccinated with the $C P-B T V$ can be distinguished from those previously infected with BTV (DIVA). Whereas all control and low dose vaccinates, and one of the four medium dose vaccinated sheep seroconverted by cELISA at 14 days after challenge infection, the three other medium dose and all of the high dose vaccinated sheep remained seronegative by cELISA following challenge. Furthermore, whereas the four control and one low dose vaccinated sheep all developed marked fever $\left(>103.5^{\circ} \mathrm{F}\right)$ by day $6-7$ after challenge infection, three of the four low dose vaccinates and all sheep immunized with either medium or high doses of the CP-BTV construct were resistant to challenge infection as determined by the absence of fever. Viral RNA was not detected by quantitative RTPCR (qRT-PCR) in the blood any of the high dose vaccinated sheep, and in only one of the four medium dose vaccinated sheep. In contrast, all of the control and low dose vaccinated became infected after challenge as confirmed by qRT-PCR analysis of their blood (Table 1).

In summary, these studies confirm that induction of protective immunity in sheep can be accomplished by immunization with only the BTV outer capsid proteins, and that there is a titratable response to vaccination such that immunization with relatively large quantities of the CP-BTV construct can induce sterilizing immunity whereas lower doses protect against development of clinical signs following challenge but not infection. This immunity is somewhat correlated to induction of neutralizing antibody in serum, however the data further suggest that animals with a minimal neutralizing antibody response following vaccination may be primed to more quickly and effectively respond to challenge infection. Similar observations of immune "priming" have been made with other recombinant vaccine constructs that utilize other expression vectors such as capripox and myxoma viruses (Perrin et al., 2007; Top et al., 2012), and with other CP-vectored animal vaccines such as that to West Nile virus (Gardner et al., 2007).

\section{Vaccinology}

A thorough understand of the immune response to animals to BTV infection is central to the logical development of efficacious vaccines, which is important because at-risk countries typically use vaccination of livestock to control any incursion or outbreak of BT (Maclachlan and Mayo, 2013). Early investigators recognized that livestock that recovered from BT were often resistant to the disease, which spurred initial efforts to develop vaccines (Spreull, 1905). However, it was later recognized that vaccination can be problematic given the plurality of BTV serotypes (currently 26) coupled with serotype-specific immunity in livestock, meaning that vaccines potentially have to be developed to all 26 currently recognized BTV serotypes (reviewed: Noad and Roy, 2009; Oya Alpar et al., 2009; Savini et al., 2008; Stewart et al., 2012; Zientara et al., 2010). Furthermore, there are few available commercial vaccine products for BTV other than the live-attenuated (modified live virus [MLV]) vaccines that continue to be used to prevent BT among commercial sheep in several areas of the world (e.g. South Africa, the United States of America). MLV vaccines are relatively inexpensive to produce and they are effective as they can induce protective immunity similar to that which follows natural infection. Despite these attributes, the use of inactivated vaccines is increasingly preferred as inactivated vaccines enjoy several inherent advantages over MLV vaccines. Specifically, as compared to MLV vaccines, inactivated vaccines cannot cause disease or revert to virulence, reassort genes with field or MLV viruses, nor cross the placenta to cause reproductive losses (reviewed: Maclachlan and Mayo, 2013; Noad and Roy, 2009; Savini et al., 2008; Stewart et al., 2012; Zientara et al., 2010). However, inactivated vaccines suffer from their relative slow onset of immunity as compared to MLV vaccines, and the lack of commercial products for most BTV serotypes.

Although not yet available commercially, replication defective vaccine viruses produced using reverse genetics technology offer the potential for vaccine constructs that combine the benefits of MLV vaccines with the safety of inactivated ones (Celma et al., 2013; Matsuo et al., 2011). Other "next generation" products such as baculovirus-expressed virus like particles (VLPs) and viralvectored recombinant vaccines, including the $\mathrm{CP}-\mathrm{BTV}$ recombinant described earlier, have been shown to be effective experimentally but their inherent cost and limited market potential have prevented their commercial use to date (Boone et al., 2007; Celma et al., 2013; Noad and Roy, 2009; Stewart et al., 2010).

The recent availability of IFNAR mice as an experimental model system has further facilitated the study of immunity to BTV infection, and to the development of potentially efficacious vaccine constructs (Calvo-Pinilla et al., 2009a, 2010). IFNAR mice can be protected against lethal BTV challenge by neutralizing antibodies induced by immunization with recombinant VP2 alone or in combination with other viral proteins (Calvo-Pinilla et al., 2009b, 2012; Franceschi et al., 2011; Jabbar et al., 2013; Ma et al., 2012). Immunization of IFNAR mice with individual or cocktails of recombinant BTV proteins also can induce varying degrees of heterotypic immunity associated with the production of protein-specific CD8+ T cells (Calvo-Pinilla et al., 2012). It is to be stressed, however, that although the IFNAR murine model provides a useful model for initial screening of potential vaccines, validation in ruminant livestock 
is clearly required and particularly in situations where the Type I IFN response may be critical to the stimulation of critical acquired immune responses.

In summary, although ongoing studies have repeatedly confirmed that a recombinant subunit vaccination strategy is viable for protection of livestock against BTV infection, the expression of immunogenic VP2 can be challenging given the conformational nature of individual epitopes and their stability during storage, and because of the apparently serotype-specific nature of immunity to BTV infection of livestock (DeMaula et al., 2000; Savini et al., 2008; Stewart et al., 2012; Zientara et al., 2010). Thus, current vaccination strategies to prevent BTV infection of livestock continue to be reliant on historic technologies, with all of their attendant potential disadvantages (Maclachlan and Mayo, 2013; Savini et al., 2008).

\section{Acknowledgements}

The authors thank Dr. Damien Vitour for his constructive review of the manuscript. Portions of these studies were supported by USDA NRI Competitive Grant \#2002-35204-12314, and funds provided by the Harriet E. Pfleger Foundation.

\section{References}

Afshar, A., 1994. Bluetongue: laboratory diagnosis. Comparative Immunology, Microbiology and Infectious Diseases 17, 221-242.

Anderson, J., 1984. Use of monoclonal antibody in a blocking ELISA to detect groupspecific antibodies to bluetongue virus. Journal of Immunological Methods 74, 139-149.

Andrew, M.E., Whiteley, P., Janardhana, V., Lobato, Z., Gould, A., Coupar, B., 1995. Antigen specificity of the ovine cytotoxic T lymphocyte response to bluetongue virus. Veterinary Immunology and Immunopathology 47, 311-322.

Appleton, J.A., Letchworth, G.J., 1983. Monoclonal antibody analysis of serotyperestricted and unrestricted bluetongue viral antigenic determinants. Virology 124, 286-299.

Barratt-Boyes, S.M., Maclachlan, N.J., 1994. The dynamics of viral spread in bluetongue virus infected calves. Veterinary Microbiology 40, 361-371.

Barratt-Boyes, S.M., Maclachlan, N.J., 1995. Pathogenesis of bluetongue virus infection of cattle. Journal of the American Veterinary Medical Association 206, $1322-1329$.

Barratt-Boyes, S.M., Rossitto, P.V., Stott, J.L., Maclachlan, N.J., 1992. Flow cytometric analysis of in vitro bluetongue virus infection of bovine blood mononuclear cells. Journal of General Virology 73, 1953-1960.

Barratt-Boyes, S.M., Rossitto, P.V., Taylor, B.C., Ellis, J.A., Maclachlan, N.J., 1995 Response of the regional lymph node to bluetongue virus infection. Veterinary Immunology and Immunopathology 45, 73-84.

Bonneau, K.R., DeMaula, C.D., Mullens, B.A., Maclachlan, N.J., 2002. Duration of viraemia infectious to Culicoides sonorensis in bluetongue virus-infected cattle and sheep. Veterinary Microbiology 88, 115-125.

Boone, J.D., Balasuriya, U.B., Karaca, K., Audonnet, J.C., Yao, J., He, L., Nordgren, R., Monaco, F., Savini, G., Gardner, I.A., Maclachlan, N.J., 2007. Recombinant canarypox virus vaccine co-expressing genes encoding the VP2 and VP5 outer capsid proteins of bluetongue virus induces high level protection in sheep. Vaccine 25, 672-678.

Borden, E.C., Shope, R.E., Murphy, F.A., 1971. Physiochemical and morphological relationships of some arthropod-borne viruses to bluetongue virus - a new taxonomic group. Physiochemical and serological studies. Journal of General Virology 13, 261-271.

Brewer, A.W., Maclachlan, N.J., 1992. Ultrastructural characterization of the interaction of bluetongue virus with bovine erythrocytes in vitro. Veterinary Pathology 29, 356-359

Brewer, A.W., Maclachlan, N.J., 1994. The pathogenesis of bluetongue virus infection of bovine blood cells in vitro: ultrastructural characterization. Archives of Virology 136, 287-298.

Calvo-Pinilla, E., Rodriguez-Calvo, J., Anguita, T., Sevilla, N., Ortego, J., 2009a. Establishment of a bluetongue virus infection model in mice that are deficient in alpha/beta interferon receptor. PLos One 4, e5171.

Calvo-Pinilla, E., Rodriguez-Calvo, T., Sevilla, N., Ortego, J., 2009b. Heterologous prime boost vaccination with DNA and recombinant vaccinia virus Ankara protects IFNAR (-/-) mice against lethal bluetongue infection. Vaccine 28, 437-445.

Calvo-Pinilla, E., Nieto, J.M., Ortego, J., 2010. Experimental oral infection of bluetongue virus serotype 8 in type 1 interferon receptor-deficient mice. Journal of General Virology 91, 2821-2825.

Calvo-Pinilla, E., Navasa, N., Anguita, J., Ortego, J., 2012. Multiserotype protection elicited by a combinational prime-boost vaccination strategy against bluetongue virus. PLoS One 7, e34735.

Celma, C.C., Boyce, M., van Rijn, P.A., Eschbaumer, M., Wernike, K., Hoffmann, B., Beer, M., Haegerman, A., De Clerq, K., Roy, P., 2013. Rapid generation of replication-deficient monovalent and multivalent vaccines for bluetongue virus: protection against virus challenge in cattle and sheep. Journal of Virology 87 9856-9864.

Channappanavar, R., Singh, K.P., Singh, R., Umeshappa, C.S., Ingale, S.L., Pandey, A.B., 2012. Enhanced proinflammatory cytokine activity during experimental bluetongue virus-1 infection in Indian native sheep. Veterinary Immunology and Immunopathology 145, 485-492.

Chauveau, E., Doceul, V., Lara, E., Adam, M., Bread, E., Sailleau, C., Viarouge, C., Desprat, A., Meyer, G., Schartz-Cornil, I., Ruscanu, S., Charley, B., Zientara, S., Vitour, D., 2012. Sensing and control of bluetongue virus infection in epithelial cells via RIG-1 and MDA5 helicases. Journal of Virology 86, 11789-11799.

Chauveau, E., Doceul, V., Lara, E., Brard, E., Sailleau, C., Vidalain, P.O., Meurs, E.F. Dabo, S., Schwartz-Cornil, I., Zientara, S., Vitour, D., 2013. NS3 of bluetongue virus interferes with the induction of type I interferon. Journal of Virology 87 $8241-8246$

Cowley, J.A., Gorman, B.M., 1987. Cross-neutralization of genetic reassortants of bluetongue virus serotypes 20 and 21. Veterinary Microbiology 19, 37-51.

Darpel, K.E., Monaghan, P., Simpson, J., Anthony, S.J., Veronesi, E., Brooks, H.W., Elliot, H., Brownlie, J., Takamatsu, H.H., Mellor, P.S., Mertens, P.P., 2012. Involvement of the skin during bluetongue virus infection and replication in the ruminant host. Veterinary Research 43, 40.

Deal, E.M., Lahl, K., Narvaez, C.F., Butcher, E.C., Greenberg, H.B., 2013. Plasmacytoid dendritic cells promote rotavirus-induced human and murine B cell responses. Journal of Clinical Investigation 123, 2464-2474.

DeMaula, C.D., Heidner, H.W., Rossitto, P.V., Pierce, C.M., Maclachlan, N.J., 1993. Neutralization determinants of United States bluetongue virus serotype 10. Virology 195, 292-296.

DeMaula, C.D., Bonneau, K.R., Maclachlan, N.J., 2000. Changes in the outer capsid proteins of bluetongue virus serotype 10 that abrogate neutralization by monoclonal antibodies. Virus Research 67, 59-66.

DeMaula, C.D., Jutila, M.A., Wilson, D.W., Maclachlan, N.J., 2001. Infection kinetics, prostacyclin release and cytokine-mediated modulation of the mechanism of cell death during bluetongue virus infection of cultured ovine and bovine pulmonary artery and lung microvascular endothelial cells. Journal of General Virology 82, 787-794

DeMaula, C.D., Leutenegger, C.M., Bonneau, K.R., Maclachlan, N.J., 2002. The role of endothelial cell-derived inflammatory and vasoactive mediators in the pathogenesis of bluetongue. Virology 296, 33-337.

Di Gialleonardo, L., Migliaccio, P., Teodori, L., Savini, G., 2011. The length of BTV8 viremia in cattle according to infection doses and diagnostic techniques. Research in Veterinary Science 91, 316-320.

Drew, C.P., Heller, M.C., Mayo, C., Watson, J.L., Maclachlan, N.J., 2010a. Bluetongue virus infection activates bovine monocyte-derived macrophages and pulmonary artery endothelial cells. Veterinary and Immunology Immunopathology 136 292-296.

Drew, C.P., Gardner, I.A., Mayo, C.E., Matsuo, E., Roy, P., Maclachlan, N.J., 2010b. Bluetongue virus infection alters the impedance of monolayers of bovine endothelia cells as a result of cell death. Veterinary Immunology and Immunopathology $138,108-115$

Dungu, B., Gerdes, T., Smit, T., 2004. The use of vaccination in the control of bluetongue in southern Africa. Veterinaria Italiana 40, 616-622.

Ellis, J.A., Luedke, A.J., Davis, W.C., Wechsler, S.J., Mecham, J.O., Pratt, D.L., Elliot, J.D. 1990. T-lymphocyte subset alterations following bluetongue virus in sheep and cattle. Veterinary Immunology and Immunopathology 24, 49-67.

Ellis, J.A., Luedke, A.J., Nunamaker, C.E., Nunamaker, R.A., Haven, T.R., 1991. Cutaneous lymphoid traffic in sheep infected with bluetongue virus. Veterinary Pathology 28, 175-180.

Foster, N.M., Luedke, A.J., Parsonson, I.M., Walton, T.E., 1991. Temporal relationships of viremia, interferon activity, and antibody responses of sheep infected with several bluetongue virus strains. American Journal of Veterinary Research 52 192-196.

Franceschi, V., Capocefalo, A., Calvo-Pinilla, E., Redaelli, M., Mucignatt-Caretta, C., Mertens, P., Ortego, J., Donofrio, G., 2011. Immunization of knock-out $\alpha \beta$ interferon receptor mice against lethal bluetongue virus infection with a BoHV4based vector expressing BTV8 VP2 antigen. Vaccine 29, 3074-3082.

Fulton, R.W., Pearson, N.J., 1982. Interferon induction in bovine and feline monolayer cultures by bluetongue virus serotypes. Canadian Journal of Comparative Medicine 46, 100-102

Gardner, I.A., Wong, S.J., Ferraro, G.L., Balasuriya, U.B., Hullinger, P.J., Wilson, W.D. Shi, P.Y., Maclachlan, N.J., 2007. Incidence and effects of West Nile virus infection in vaccinated and unvaccinated horses in California. Veterinary Research 38, $109-116$.

Gibbs, E.P., Greiner, E.C., 1994. The epidemiology of bluetongue. Comparative Immunology, Microbiology and Infectious Diseases 17, 207-220.

Gibbs, E.P., Tabachnick, W.J., Holt, T.J., Stallknecht, D.E., 2008. U.S. concerns of bluetongue. Science 320, 672

Gould, A.R., Hyatt, A.D., Eaton, B.T., 1988. Morphogenesis of a bluetongue virus variant with an amino acid alteration at a neutralization site in the outer coat protein VP2. Virology 165, 23-32.

Gould, A.R., Eaton, B.T., 1990. The amino acid sequence of the outer coat protein VP2 of neutralizing resistant monoclonal antibody-resistant virulent and attenuated bluetongue viruses. Virus Research 17, 161-172.

Grubman, M.J., Appleton, J.A., Letchworth, G.J., 1983. Identification of bluetongue virus type 17 genome segments coding for polypeptides associated with virus neutralization and intergroup reactivity. Virology 131, 355-366. 
Guis, H., Caminade, C., Calvete, C., Morse, A.P., Tran, A., Baylis, M., 2012. Modeling the effects of past and future climate on the risk of bluetongue emergence in Europe. Journal of the Royal Society Interface 9, 339-350.

Heidner, H.W., Rossitto, P.V., Maclachlan, N.J., 1990. Identification of four distinct neutralizing epitopes on bluetongue virus serotype 10 using neutralizing monoclonal antibodies and neutralization-escape variants. Virology 176, 658-661.

Hemati, B., Contreras, V., Urien, C., Bonneau, M., Takamatsu, H.H., Mertens, P.P., Breard, E., Sailleau, C., Zientara, S., Schwartz-Cornil, I., 2009. Bluetongue virus targets conventional dendritic cells in skin lymph. Journal of Virology 83, 8789-8799.

Hofmann, M.A., Renzullo, S., Mader, M., Chaignat, V., Worwa, G., Thuer, B., 2008. Genetic characterization of Toggenburg Orbivirus, a new bluetongue virus, from goats, Switzerland. Emerging Infectious Diseases 14, 1855-1861.

Huismans, H., 1969. Bluetongue virus-induced interferon synthesis Onderstepoort. Journal of Veterinary Research 36, 181-185.

Huismans, H., Erasmus, B.J., 1981. Identification of the serotype-specific and groupspecific antigens of bluetongue virus. Onderstepoort Journal of Veterinary Research 48, 51-58.

Huismans, H., van der Walt, N.T., Cloete, M., Erasmus, B.J., 1987. Isolation of a capsid protein of bluetongue virus that induces a protective immune response in sheep. Virology 157, 172-179.

Hutcheon, D., 1902. Malarial catarrhal fever of sheep. Veterinary Record 14, 629-633.

Jabbar, T.K., Calvo-Pinilla, E., Mateos, F., Gubbins, S., Bin-Tarif, A., BachanekBankowska, K., Alpar, O., Ortego, J., Takamatsu, H.H., Mertens, P.P., CastilloOlivares, J., 2013. Protection of IFNAR $(-/-)$ mice against bluetongue virus serotype 8 , by heterologous (DNA/rMVA) and homologous (rMVA/rMVA) vaccination, expressing outer-capsid protein VP2. PLoS One 8, e60574.

Janardhana, V., Andrew, M.E., Lobato, Z.I., Coupar, B.E., 1999. The ovine cytotoxic T lymphocyte responses to bluetongue virus. Research in Veterinary Science 67. 213-221.

Jeggo, M.H., Wardley, R.C., 1982a. Generation of cross-reactive cytotosic T lymphocytes following immunization of mice with various bluetongue virus types. Immunology 45, 629-635.

Jeggo, M.H., Wardley, R.C., 1982b. The induction of murine cytotoxic T lymphocytes by bluetongue virus. Archives of Virology 71, 197-206.

Jeggo, M.H., Wardley, R.C., Brownlie, J., 1984. A study of the role of cell-mediated immunity in bluetongue virus infection in sheep using cellular adoptive transfer techniques. Immunology 52, 403-410.

Jeggo, M.H., Wardley, R.C., Brownlie, J., Corteyn, A.H., 1986. Serial inoculation of sheep with two bluetongue virus types. Research in Veterinary science 40, 386-392.

Jiminez-Clavero, M.A., 2012. Animal viral diseases and global change: bluetongue and West Nile fever as paradigms. Frontiers in Genetics 3, 105.

Jones, L.D., Chuma, T., Hails, R., Williams, T., Roy, P., 1996. The non-structural proteins of bluetongue virus are a dominant source of cytotoxic $\mathrm{T}$ cell peptide determinants. Journal of General Virology 77, 997-1003.

Jones, L.D., Williams, T., Bishop, D., Roy, P., 1997. Baculovirus expressed nonstructural protein NS2 of bluetongue virus induces a cytotoxic T-cell response in mice which affords partial protection. Clinical and Diagnostic Laboratory Immunology 4, 297-301.

Lee, F., Chen, J.L., Lin, C.M., Wang, F.L., 2011. Presence of bluetongue virus in the marginal zone of the spleen in acute infected sheep. Veterinary Microbiology 152, 96-100.

Levy, D.E., Marie, I.J., Durbin, J.E., 2011. Induction and function of type I and III interferon in response to viral infection. Current Opinion in Virology 6, 476-486.

Lobato, Z.I., Coupar, B.E., Gray, C.P., Lunt, R., Andrew, M.E., 1997. Antibody responses and protective immunity to recombinant vaccinia virus-expressed bluetongue virus antigens. Veterinary Immunology and Immunopathology 59, 293-309.

Luedke, A.J., Jochim, M.M., Jones, R.H., 1969. Bluetongue in cattle: viremia. American Journal of Veterinary Research 30, 511-516.

Ma, G., Eschbaumer, M., Said, A., Hoffmann, B., Beer, M., Osterrieder, N., 2012. An equine herpesvirus type 1 (EHV-1) expressing VP2 and VP5 of serotype 8 bluetongue (BTV-8) induces protection in a murine infection model. PloS One 7 , e34425

Maan, N.S., Maan, S., Belaganahalli, M.N., Ostlund, E.N., Johnson, D.J., Nomikou, K., Mertens, P.P., 2012. Identification and differentiation of the twenty six bluetongue virus serotypes by RT-PCR amplification of the serotype-specific genome segment 2. Plos One 7, e32601.

Maclachlan, N.J., 2011. Bluetongue: history, global epidemiology, and pathogenesis. Preventive Veterinary Medicine 102, 107-111.

Maclachlan, N.J., Guthrie, A.J., 2010. Re-emergence of bluetongue African horse sickness, and other Orbivirus diseases. Veterinary Research 41, 35.

Maclachlan, N.J., Mayo, C.E., 2013. Potential strategies for control of bluetongue, a globally emerging Culicoides transmitted viral disease of ruminant livestock and wildlife. Antiviral Research 99, 79-90.

Maclachlan, N.J., Osburn, B.I., 2006. Impact of bluetongue virus infection on the international movement and trade of ruminants. Journal of the American Veterinary Medical Association 228, 1346-1349.

Maclachlan, N.J., Thompson, J., 1985. Bluetongue virus-induced interferon in cattle. American Journal of Veterinary Research 46, 1238-1241.

MacLachlan, N.J., Schore, C.E., Osburn, B.I., 1984. Antiviral responses of bluetongue virus-inoculated bovine fetuses and their dams. American Journal of Veterinary Research 45, 1469-1473.

Maclachlan, N.J., Heidner, H.W., Fuller, F.J., 1987. Humoral immune response of calves to bluetongue virus infection. American Journal of Veterinary Research 48, 1031-1035.
Maclachlan, N.J., Jagels, G., Rossitto, P.V., Moore, P.F., Heidner, H.W., 1990. The pathogenesis of experimental bluetongue virus infection of calves. Veterinary Pathology 27, 223-229.

Maclachlan, N.J., Rossitto, P.V., Heidner, H.W., Iezzi, L.G., Yilma, T.D., DeMaula, C.D. Osburn, B.I., 1992. Variation amongst the neutralizing epitopes of bluetongue viruses isolated in the United States 1979-1981. Veterinary Microbiology 31 303-316.

Maclachlan, N.J., Nunamaker, R.A., Katz, J.B., Sawyer, M.M., Akita, G.Y., Osburn, B.I., Tabachnick, W.J., 1994. Detection of bluetongue virus in the blood of inoculated calves: comparison of virus isolation. PCR assay, and the in vitro feeding of Culicoides variipennis. Archives of Virology 136, 1-8.

Maclachlan, N.J., Crafford, J.E., Vernau, W., Gardner, I.A., Goddard, A., Guthrie, A.J., Venter, E.H., 2008. Experimental reproduction of severe bluetongue in sheep. Veterinary Pathology 45, 31-315.

Maclachlan, N.J., Drew, C.P., Darpel, K.E., Worwa, G., 2009. The pathology and pathogenesis of bluetongue. Journal of Comparative Pathology 141, 1-16.

Mahrt, C.R., Osburn, B.I., 1986. Experimental bluetongue virus infection of sheep: effect of vaccination: pathologic, immunofluorescent, and ultrastructural studies. American Journal of Veterinary Research 47, 1198-2103.

Martinelle, L., Dal Pozzo, F., Sarradin, P., De Leeuw, I., De Clercq, K., Ziant, D., Thiry, E., Saegerman, C., 2011. Two alternative inocula to reproduce bluetongue virus serotype 8 disease in calves. Vaccine 29, 3600-3609.

Matsuo, E., Roy, P., 2013. Minimum requirements for bluetongue virus primary replication in vivo. Journal of Virology 87, 882-889.

Matsuo, E., Celma, C.C., Boyce, M., Viarouge, C., Sailleau, C., Dubois, E., Bread, E., Thiery, R., Zientara, S., Roy, P., 2011. Generation of replication-defective virusbased vaccines that confer protection if sheep against virulent bluetongue virus challenge. Journal of Virology 85, 10213-10221.

Mellor, P.S., Boorman, J., Baylis, M., 2000. Culicoides biting midges: their role as arbovirus vectors. Annual Reviews of Entomology 45, 307-340.

Mertens, P.P., Brown, F., Sangar, D.V., 1984. Assignment of the genome segments of bluetongue virus type 1 to the proteins they encode. Virology 135, 207-217.

Mertens, P.P., Pedley, S., Cowley, J., Burroughs, J.N., Corteyn, A.H., Jeggo, M.H., Jennings, D.M., Gorman, B.M., 1989. Analysis of the roles of bluetongue virus outer capsid proteins VP2 and VP5 in determination of virus serotype. Virology 170 561-565.

Murphy, F.A., Borden, E.C., Shope, R.E., Harrison, A., 1971. Physiochemical and morphological relationships of some arthropod-borne viruses to bluetongue virus-a new taxonomic group. Electron microscopic studies. Journal of General Virology $13,273-288$

Noad, R., Roy, P., 2009. Bluetongue vaccines. Vaccine 27 (Suppl. 4), D86-D89.

Osburn, B.I., Maclachlan, N.J., Terrell, T.G., 1982. Ontogeny of the immune system. Journal of the American Veterinary Medical Association 181, 1049-1052.

Oya Alpar, H., Bramwell, V.W., Veronesi, E., Darpel, K.E., Pastoret, P.P., Mertens P.P., 2009. Bluetongue virus vaccines past and present. In: Mellor, P., Baylis, M. Mertens, P. (Eds.), Bluetongue. Elsevier, Amsterdam, pp. 397-428.

Pierce, C.M., Rossitto, P.V., Maclachlan, N.J., 1995. Homotypic and heterotypic neutralization determinants of bluetongue virus serotype 17. Virology 209, 263-267.

Pini, A., 1976. Study on the pathogenesis of bluetongue; replication of the virus in the organs of infected sheep. Onderstepoort Journal of Veterinary Research 43 , $159-164$.

Perrin, A., Albina, E., Breard, E., Sailleau, C., Prome, S., Grillet, C., Kwiatek, O., Russo, P., Thiery, R., Zientara, S., Cetre-Sossah, C., 2007. Recombinant capripoxviruses expressing the proteins of bluetongue virus: evaluation of immune responses and protection in small ruminants. Vaccine 25, 6774-6783.

Purse, B.V., Brown, H.E., Harrup, L., Mertens, P.P., Roger, D.J., 2008. Invasion of bluetongue and other Orbivirus infections into Europe: the role of biological and climatic processes. OIE Scientific and Technical Review 27, 427-442.

Ratinier, M., Caporale, M., Golder, M., Franzoni, G., Allan, K., Nunes, S.F., Armezzani, A Bayoumy, A., Rixon, F., Shaw, A., Palmarini, M., 2011. Identification and characterization of a novel non-structural protein of bluetongue virus. PLoS Pathogens 7, e1002477.

Richards, R.G., Maclachlan, N.J., Heidner, H.W., Fuller, F.J., 1988. Comparison of virologic and serologic responses of lambs and calves infected with bluetongue virus serotype 10. Veterinary Microbiology 18, 233-242.

Ristow, S., Leendersten, L., Gorham, J., Yilma, T., 1988. Identification of a neutralizing epitope shared by bluetongue virus serotypes 2 and 13. Journal of Virology 62 2502-2504

Rossitto, P.V., Maclachlan, N.J., 1992. Neutralizing epitopes of the serotypes of bluetongue virus present in the United States. Journal of General Virology 73 1947-1952

Roy, P., Urakawa, T., Van Dijk, A.A., Erasmus, B.J., 1990. Recombinant virus vaccine for bluetongue disease in sheep. Journal of Virology 64, 1998-2003.

Roy, P., French, T., Erasmus, B.J., 1992. Protective efficacy of virus-like particles for bluetongue disease. Vaccine 10, 28-32.

Roy, P., Bishop, D.H., LeBois, H., Erasmus, B.J., 1994. Long lasting protection of sheep against bluetongue challenge after vaccination with virus-like particles: evidence for homologous and partial heterologous protection. Vaccine 12 805-811.

Ruscanu, S., Pascale, F., Bourge, M., Hemati, B., Elhmouzi-Younes, J., Urien, C., Bonneau, M., Takamatsu, H., Hope, J., Mertens, P., Meyer, G., Stewart, M., Roy, P., Meurs, E.F., Dabo, S., Zientara, S., Breard, E., Sailleau, C., Chauveau, E., Vitour, D. Charley, B., Schwartz-Cornil, I., 2012. The double-stranded RNA bluetongue virus induces type I interferon in plasmacytoid dendritic cells via a MYD88-dependent TLR7/8-independent signaling pathway. Journal of Virology 86, 5817-5828. 
Ruscanu, S., Jouneau, L., Urien, C., Bourge, M., Lecardonnel, J., Moroldo, M., Loup, B., Dalod, M., Elhmouzi-Younes, J., Bevilacqua, C., Hope, J., Vitour, D., Zientara, S., Meyer, G., Schwartz-Cornil, I., 2013. Dendritic cell subtypes from lymph nodes and blood show contrasted gene expression programs upon Bluetongue virus infection. Journal of Virology 87, 9333-9343.

Russell, H., O’Toole, D.T., Bardsley, K., Davis, W.C., Ellis, J.A., 1996. Comparative effects of bluetongue virus infection of ovine and bovine endothelial cells. Veterinary Pathology 33, 319-331.

Saegerman, C., Berkvens, D., Mellor, P.S., 2008. Bluetongue epidemiology in the European Union. Emerging Infectious Diseases 14, 539-544.

Sanchez-Cordon, P.J., Plequezuelos, F.J., Perez de Diego, A.C., Gomez-Villamandos, J.C., Sanchez-Vizcaino, J.M., Ceron, J.J., Tecies, F., Garfia, B., Pedrera, M., 2013. Comparison study of clinical courses, gross lesions, acute phase response and coagulation disorders in sheep inoculated with bluetongue virus serotype 1 and 8. Veterinary Microbiology 166, 184-194.

Savini, G., Maclachlan, N.J., Sanchez-Vizcaino, J.M., Zientara, S., 2008. Vaccines against bluetongue in Europe. Comparative Immunology. Microbiology and Infectious Diseases 31, 101-120.

Schwartz-Cornil, I., Mertens, P.P/., Contreras, V., Hemati, B., Pascale, F., Breard, E., Mellor, P.S., Maclachlan, N.J., Zientara, S., 2008. Bluetongue virus: virology, pathogenesis and immunity. Veterinary Research 39, 46.

Spreull, J., 1905. Malarial catarrhal fever (bluetongue) of sheep in South Africa. Journal of Comparative Pathology and Therapeutics 18, 321-337.

Stewart, M., Bhatia, Y., Athmaran, T.N., Noad, R., Gastaldi, C., Dubios, E., Russo, P. Thiery, R., Sailleau, C., Breard, E., Zientara, S., Roy, P., 2010. Validation of a novel approach for the rapid production of immunogenic virus-like particles for bluetongue virus. Vaccine 28, 3047-3054.

Stewart, M., Dovas, C.L., Chatzinasiou, E., Athmaram, T.N., Papanastassopoulo, M. Papdoulos, O., Roy, P., 2012. Protective efficacy of bluetongue virus-like and subvirus-like particles in sheep: presence of the serotype-specific VP2, independent of its geographic lineage, is essential for protection. Vaccine 30, 2131-2139.

Tabachnick, W.J., 2010. Challenges in predicting climate and environmental effects on vector-borne disease episystems in a changing world. Journal of Experimental Biology 213, 946-954.
Takamatsu, H., Jeggo, M.H., 1989. Cultivation of bluetongue virus-specific vine T cells and their cross-reactivity with different serotype viruses. Immunology 66, 258-263.

Thomas, F.C., 1985. Plaque neutralization cross reactivity of post infection bovine sera amongst bluetongue virus serotypes. Progress in Clinical and Biological Research 178, 511-512.

Top, S., Foucras, G., Deplanche, M., Rives, G., Calvalido, J., Comtet, L., Bertagnoli, S., Meyer, G., 2012. Myxomavirus as a vector for immunization of sheep: protection study against challenge with bluetongue virus. Vaccine 30, 1609-1616.

Umeshappa, C.S., Singh, K.P., Nanjjundappa, R.H., Channappanavar, R., Maan, S. Mann, N.S., 2012. Bluetongue virus-23 stimulates inducible nitric oxide synthase expression and nitric oxide production in mononuclear cells of blood and/or regional lymphoid organs. Veterinary Research Communications 36, 245-250.

Velthuis, A.G., Saatkamp, H.W., Mourits, M.C., de Koejier, A.A., Elbers, A.R., 2010. Financial consequences of the Dutch bluetongue serotype 8 epidemics of 2006 and 2007. Preventive Veterinary Medicine 93, 294-304.

Verwoerd, D.W., Erasmus, B.J., 2004. Bluetongue. In: Coetzer, J.A., Tustin, R.C. (Eds.), Infectious Diseases of Livestock. , 2nd ed. Oxford Press, Cape Town, pp. $1201-1220$

Verwoerd, D.W., Els, H.J., De Villiers, E.M., Huismans, H., 1972. Structure of the bluetongue virus capsid. Journal of Virology 10, 783-794.

Weaver, S.C., Reisen, W.K., 2010. Present and future arboviral threats. Antiviral Research 85, 328-345.

Whetter, L.E., Maclachlan, N.J., Gebhard, D.H., Heinder, H.W., Moore, P.F., 1989 Bluetongue virus infection of bovine moncytes. Journal of General Virology 70 , 1663-1676.

White, J.R., Eaton, B.T., 1990. Conformation of the VP2 protein of bluetongue virus (BTV) determines the involvement in virus neutralization of highly conserved epitopes within the BTV serogroup. Journal of General Virology 71, 1325-1332.

Zientara, S., MacLachlan, N.J., Calistri, P., Sanchez-Vizcaino, J.M., Savini, G., 2010. Bluetongue vaccination in Europe. Expert Reviews of Vaccines 9, 989-991. 